Business and Economics Research Journal

Volume 8 Number 32017

pp. $555-573$

ISSN: $1309-2448$

DOI Number: 10.20409/berj.2017.66

\title{
Sigara Paketlerinde Bulunan Birleşik Sağlık Uyarılarının Etkinliğinin Sosyal Pazarlama Açısından Değerlendirilmesi
}

\author{
Murat Aktan ${ }^{a}$
}

\begin{abstract}
Öz: Sigara içmek bireylerin sağlığını olumsuz bir şekilde etkilediği gibi; tütün ürünlerinin neden olduğu sağlık problemleri ekonomi üzerinde önemli bir yük teşkil etmektedir. Bu bakımdan, sigarayla olan mücadele devletleri ilgilendiren bir konudur. Türkiye Sağlık Bakanlığı, sigara paketleri üzerinde 14 farklı yazılı ve görsel sağlık uyarısının (birleşik uyarı) bulunmasını 2010 yılından beri zorunlu kılmıştır. Buna karşın, birleşik uyarıların ne ölçüde etkili olduğu konusu tam olarak bilinmemektedir. Bu bakımdan, bu araştırma yürürlükte olan 14 birleşik uyarısını etkinlik açısından değerlendirmeyi amaçlamaktadır. Çalışmada katılımcılardan açık uçlu sorular ile etkili buldukları uyarıları değerlendirmeleri istenmiş; frekans analizi ile en etkili bulunan 3 görsel belirlenmiştir. Ayrıca ki-kare analiziyle en etkili bulunan 3 birleşik sağlık uyarısı ile cinsiyet, yaş ve sigara içme düzeyleri arasındaki ilişki test edilmiştir. Sonuçlar, cinsiyet ve sigara içme düzeyleriyle görsellerin etkili bulunmasının birbirinden bağımsız olmadığını ortaya koymuştur. Buna göre birleşik sağlık uyarılarını etkili bulan kadın katılımcıların sayısı, erkek katılımcılara oranla daha fazladır. Benzer şekilde sigara içme miktarı azaldıkça, daha fazla oranda katılıma, birleşik sağlık uyarılarını etkili bulduğunu ifade etmiştir. Ancak, bulgular yaş grubuyla görsellerin etkili olarak algılanma durumu arasında bir ilişkinin olmadığını ortaya koymuştur.
\end{abstract}

Anahtar Sözcükler: Sosyal Pazarlama, Bağımlılık, Sigara İçmek, Birleşik Sağlık Uyarısı

JEL Sınıflandırması: M37, M38

\section{Evaluation of the Effectiveness of Pictorial-Textual Health Warning Labels on Cigarette Packs in Terms of Social Marketing}

\begin{abstract}
Smoking negatively affects individuals' health, and health problems caused by tobacco products are an important burden on the economy. Thus, struggle against cigarette is a topic of interest for governments. Turkish Health Ministry has mandated to place 14 different textual and pictorial health warnings (graphic warning label - GWL) on cigarette packs since 2010. However, the extent of GWLs effectiveness is not fully known. Therefore, this research aims to investigate 14 GWLs in terms of their effectiveness. During research, participators were asked to evaluate each GWL which they considered effective; the most effective $3 \mathrm{GWLs}$ were determined by frequency analysis. Besides, the relations between the most effective $3 \mathrm{GWLs}$, gender, age and smoking levels were tested. Results revealed that the fact that GWLs were considered effective is not independent of gender and smoking levels. In this respect, the amount of female participants who considered GWLs as effective was proportionately higher than male respondents. In a similar vein, along with the decrease in smoking frequency, more respondents indicated that GWLs are effective. However, findings illustrated that there was no relation between age and the fact that whether GWLs are perceived as effective.
\end{abstract}

Keywords: Social Marketing, Addiction, Smoking, Health Graphic Warning Label

JEL Classification: M37, M38

${ }^{a}$ Asst. Prof., PhD., Nevsehir Haci Bektas Veli University, Faculty of Economics and Administrative Sciences, Department of International Trade and Logistics, Nevsehir, Turkiye, murat.aktan@nevsehir.edu.tr 


\section{Giriş}

Sigara her yıl dünyada yaklaşık 6 milyon insanın hayatını kaybetmesine sebep olan önemli bir sağılık sorunudur (WHO, 2015). Ülkemizde ilki 2008 yılında yapılan Küresel Yetişkin Tütün Araştırması'nın 2012 yılında yayımlanan son raporunda 15 yaş ve üstü bireylerin \% 27'sinin sigara ve herhangi başka bir tütün mamulü kullandıkları görülmektedir. Buna karşın, tütün ve tütün mamullerini bırakmayı planlayanların oranında belirtilen bu 4 sene içerisinde yaklaşık \%8'lik bir artı̧̧ olduğu görülmüştür (THSK, 2012). Benzer şekilde Türkiye'de 2009 senesi yıllık sigara tüketimi 107 milyar paketten fazlayken, yapılan yasal düzenlemelerle bu sayı 2014 senesinde 95 milyar pakete gerilemiştir (TAPDK, 2015). Sigara içme oranındaki bu azalmalara rağmen 2014 OECD raporu, Türkiye'nin Avrupa Birliği içerisinde Yunanistan, Litvanya, Kıbrıs, Hırvatistan, Estonya, İspanya, Macaristan, Sırbistan ve Fransa'dan sonra en çok sigara içilen ülke konumunda olduğunu göstermektedir. Ayrıca rapora göre, ülkemizde 15 yaş ve üstü bireylerin \% 24'ü günlük sigara tüketicisi konumundadır. Bu sonuç, sigara tüketiminin ülkemizde halen önemli bir problem olduğunu göstermektedir (OECD, 2014).

Sigara içmek bireylere ve ekonomiye uzun vadeli zararları olan tehlikeli bir alışkanlıktır. Nitekim artan sağlık harcamaları, ekonomi üzerinde önemli bir yük teşkil etmektedir. Ekpu ve Brown (2015) yüksek gelire sahip ülkelerde, sağlık masraflarının \% 15'ini tütün ürünlerinden kaynaklanan hastalıklardan oluşturduğunu belirtmiştir. Bu bakımdan sigarayla olan savaşta en temel görev aslında devlete düşmektedir. 18 - 20 Kasım 2015 tarihlerinde gerçekleştirilen Ulusal Tütün Kontrol Eylem Planı Çalıştayı, 2016 senesiyle birlikte tütünle mücadeleyi önemli bir amaç olarak belirlemiştir (Havanı Koru, 2016). Türkiye'nin sigaraya karşı geliştirmiş olduğu politikalar çerçevesinde sigara reklamları yasaklanmış, sigara ve tütün ürünlerine uygulanan vergi oranları arttırılmış ve sigara paketlerinde birleşik sağlık uyarılarının bulunması zorunlu kılınmıştır.

Sigara birleşik sağlık uyarılarının etkinliği, başta sağlık sektörü olmak üzere pazarlama ve iletişim bilim insanları tarafindan araştırılan bir konudur. Ancak, sigara birleşik sağlık uyarılarının ne kadar etkili olduğu hakkında elde edilen bulguların birbirini destekler nitelikte olmadığı görülmektedir. Buna göre bazı araştırmalar, birleşik sağlık uyarılarının etkili olmadığını ifade ederken, birleşik sağlık uyarılarının sigarayı bırakma, sigaraya başlamama anlamında faydalı olduğunu ifade eden çalışmalar da mevcuttur (Mazlum ve Mazlum, 2014; Veer ve Rank, 2012; Lindstrom ve Underhill, 2010; Cheron, 2015; Özkaya, Edinsel, Özkaya ve Hamzaçebi, 2009). Bu noktadan yola çıkan bu araştırma Türkiye'de yürürlükte olan birleşik sağlık uyarılarından hangilerinin ne oranda etkili olarak algılandığını araştırmayı amaçlamaktadır. Ayrıca, etkili olarak algılanma durumuyla ile cinsiyet, yaş ve sigara içme düzeylerinin birbirinden bağımsız olup olmadığı da araştırmanın bir diğer amacını oluşturmaktadır. Bu bakımdan araştırmanın, birleşik sağlık uyarılarının etkinliğinin anlaşılması bakımından literatüre katkı sağlayacağı düşünülmektedir.

\section{Sağlık Alanında Sosyal Pazarlamanın Kullanımı}

Pazarlama, ürünlerin hedef pazara yönelik bir şekilde üretilmesi ve satılmasına ilişkin problemlere çözüm üretmek adına geliştirilmiştir. Ancak insanların bilinç seviyesi, rekabet, ekonomi ve iletişim teknolojilerinin gelişmesiyle birlikte, pazarlamanın ilgilendiği alanlar da çeşitlenmiştir. Pazarlama günümüzde yaşamın her alanında kullanılan bir olgu haline gelmiştir. Bu kapsamda iş arayan bir bireyin deneyim ve becerilerini anlatması; politika yapıcıların fikirlerini hitap ettikleri kitlelere aktarması pazarlama uygulamalarına örnek teşkil etmektedir. Benzer şekilde, toplum yararını gözeterek birtakım olumlu davranışların gelişmesini sağlamak da pazarlamanın ilgi alanına girmektedir. İçinde bulunduğu toplum, çevre ve doğaya faydalı olmayı amaçlayan bu tür pazarlama faaliyetleri sosyal pazarlama olarak tanımlanmaktadır (Bayraktaroğlu ve iltter, 2007).

Sosyal pazarlama, hedef kitle ve topluma sunulan faydayı gözeterek yapılan pazarlama faaliyetleri olarak tanımlanmaktadır (Kotler ve Andreasen, 1996). Bu bakımdan sosyal pazarlama, pazarlama faaliyetini gerçekleştirenlerin maddi kazançlarından ziyade birey ve toplum çıkarına yönelik yapılan faaliyetlerdir. (Weinreich, 1999). Örneğin doğayı koruma, küresel ısınmayı önleme gibi çevresel konular sosyal pazarlamanın ilgi alanına girmektedir. Bu kapsamda, kamu sağlığını iyileştiren ve sağlıklı yaşamı teşvik eden pazarlama uygulamaları, sosyal pazarlama sistemi olarak değerlendirilmektedir (Upton ve Thirlaway, 2014). 
Sosyal pazarlama kavramının gelişmesi, özellikle ilk zamanlarda, Amerika Birleşik Devletleri'nde olsa da, günümüzde çoğu ülkede sosyal pazarlamanın sağlıklı yaşamın teşvikinde kullanıldığı görülmektedir. Bu bağlamda, cinsel yollarla bulaşan hastalıklardan doğum kontrol süreci ve alkolizm problemine uzanan geniş bir yelpazede, pazarlama kavramları ve teknikleri kullanılmaktadır. Dolayısıyla, Türkiye'de son yıllarda sıklıkla gördüğümüz, kalp sağlığı hakkında toplumu bilinçlendiren, obeziteyi önleyici bilgiler içeren kamu spotları ile sigara tüketimine karşı geliştirilen kampanyalar sağlıklı yaşamı teşvik eden sosyal pazarlama faaliyetlerine örnek teşkil etmektedir (Hassan, Walsh, Shiu, Hastings ve Harris, 2007). Sosyal pazarlama ile işletmelerin yapmış olduğu ticari kaygı taşıyan pazarlama faaliyetleri arasında en temelde şu tür farklılıklar bulunmaktadır: (1) daha az rekabet olması veya hiç olmaması (örn: aynı amaca hizmet eden farklı sosyal pazarlama faaliyetleri), (2) toplum lehine olan davranış değişiklikleri, fikir ve görüşler ürün olarak değerlendirilebileceği için satın alınan ürünler ve hizmetler için her zaman para ödemek zorunda olunmaması (örn: sosyal pazarlama uygulamasından sonra bireylerin herhangi bir ek maliyete katlanmadan doğal çevreyi kirletmemesi ve piknik alanlarını temiz bırakması), (3) pazarlama faaliyetleriyle tutundurulmaya çalışılan davranış değişikliğinin genellikle çok arzulanmaması (örn: kişilerden sigarayı bırakma gibi bağımlı olduğu davranışlardan vazgeçmesinin istenilmesi) (Green, Tones, Cross ve Woodall, 2015). Sağlık alanında yapılan sosyal pazarlama uygulamaları, bireylere sağılıklı yaşam ve davranış biçimlerini tutundurmaya çalışmaktadır. Pazarlama kavram ve tekniklerinin, sağlıklı davranışı teşvik etmek için kullanıımasının literatürde sağlıklı yaşam pazarlaması (health promotion) olarak kavramsallaştiğı görülmektedir (Green, Tones, Cross ve Woodall, 2015). Sağılıklı yaşam pazarlaması kavram olarak ilk kez Dünya Sağılı Örgütü’nün 1986 yılında gerçekleştirmiş olduğu, 1. Uluslararası Ottowa Sağlıklı Yaşam Pazarlama Konferansı'nda gündeme gelmiştir. Buna göre, sağlıklı yaşam pazarlaması bireylerin sağlıklarını kontrol altına almasını ve iyileştirmesini sağlayan bir süreç olarak tanımlanmıştır (WHO, 1986).

Ülkemizde özellikle son yıllarda bir sosyal pazarlama uygulaması olarak, insanların sağlıklı yaşama teşvik edilmesi bir kamu politikası haline gelmiştir. Yani bir bakıma, devlet kendi organlarıyla sağlıklı yaşam pazarlaması yaparak obezite, sigara kullanımı gibi konularda insanlar üzerinde farkındalık yaratmaya çalışmaktadır. Bu kapsamda, ilk olarak 2004 senesinde, Tütün Kontrolü Çerçeve Sözleşmesi'nin 11. Maddesi tütün mamullerinin paket ve ambalajında tütün kullanımının zararlı etkilerini anlatan uyarılar konulmasını zorunlu kılmıştır (Resmi Gazete, 2004). 01 Ocak 2006 tarihinden itibaren ise uygulama yürürlüğe konulmuş, sigara paketlerinin ön ve arka yüzlerine yazılı sağılı uyarıları yerleştirilmiştir. 27.02 .2010 tarihi 27506 sayılı Resmi Gazete'de duyurulan yönetmelik değişikliği ise birleşik sağlık uyarısına geçilmesini sağlamıştır. Resmi gazetenin kendi yapmış olduğu tanımlamaya göre yazılı ve görsel sağlık uyarılarının birlikte kullanılması birleşik sağlık uyarısı olarak isimlendirilmiştir (Resmi Gazete, 2010). Birleşik sağlık uyarılarında, yazılı sağık uyarılarının yanı sıra mesajın içeriğini destekleyen görseller sigara paketlerine uygulanmaya başlanmıştır. Şu an Türkiye'de yürürlükte olan 14 birleşik sağlık uyarısı bulunmaktadır (Şekil 1).

Sigara paketlerinde bulunan birleşik uyarılar, sosyal pazarlamanın sağlık alanında kullanılmasına bir örnek teşkil etmektedir. Bu bakımdan, birleşik uyarıların sağlıklı yaşam pazarlaması kapsamında ele alınmasının uygun olduğu düşünülmektedir. Birleşik uyarılar geleneksel pazarlama karması açısından değerlendirildiğinde, sigara paketinde bulunan mesaj içeriği ve görsellerin tutundurma faaliyeti olduğu; pazarlanmaya çalışılan davranış biçiminin yani sigara içmemenin ise ürün olduğu düşünülmektedir. Dağıtım kanalını ise sigara paketlerinin ambalajı oluşturmaktadır. Ancak daha önceden değinildiği üzere, sosyal pazarlama faaliyetlerini ticari pazarlama faaliyetlerinden ayıran önemli noktalardan bir tanesi, pazarlanan ürün için tüketicilerin genelde belirli bir ücret ödememesidir. Bu bakımdan, birleşik sağlık uyarıları vasıtasıyla tutundurulmaya çalışılan sigara kullanmama davranışı, ilaçla tedavi ve benzeri istisnai durumlar haricinde, ücret ödemeden, kişisel irade ve kararlılıkla gerçekleşen bir durumdur. Verilen örneklerden görülebileceği üzere geleneksel pazarlama karması, sosyal pazarlamanın faaliyetlerinin anlaşılmasında yardımcı olabilmektedir. Nitekim sosyal pazarlama daha önceden değinildiği gibi, pazarlama kavram ve tekniklerinin, sosyal bir çıkt için kullanılması anlamına gelmektedir. 


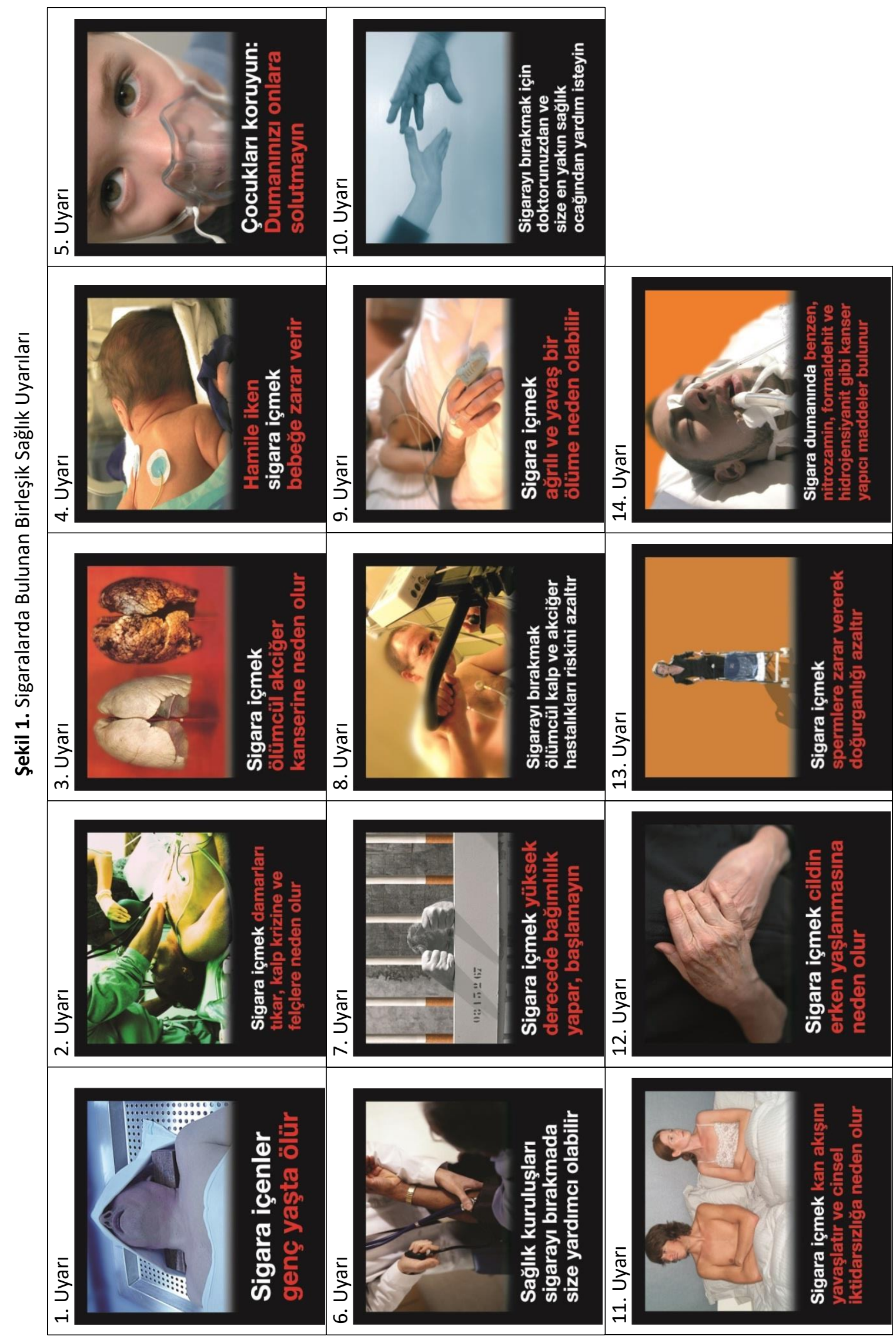




\section{Birleşik Sağlık Uyarı Görsellerinin Etkinliği}

Birleşik sağlık uyarılarının etkinliği, insanların bilinçlenmesiyle, son yıllarda araştırılan bir alan olduğu için konu hakkında çok sayıda araştırma bulunmamaktadır. Yapılan araştırmalar ise birbirini destekler sonuçlar ortaya koyamamıştır. Buna göre, sigara birleşik sağıı uyarılarının ne derece etkin olduğu konusunda yeterince kanı birliğinin oluşmadığı görülmektedir.

Sigara birleşik sağlık uyarılarının etkinliği ilk kez Hammond, Fong, McDonald, Browns, Cameron (2004) tarafindan değerlendirilmiştir. Sigara içenler üzerinde yapılan bu araştırmada katılımcıların \% 36'sı sigarada bulunan birleşik sağlık uyarılarını görmezden gelmeye çalıştğını belirtmiştir. Ayrıca, katılımcıların \% 13'ü birleşik sağıık uyarılarını inandırıı bulmadıklarını hatta abartılı gördüklerini ifade etmişlerdir. Cheron (2015) sigara içenler üzerinde yaptı̆ı araştırmada, birleşik sağlık uyarıları ile sadece yazı içeren uyarıları etkinlik açısından karşılaştırmıştır. Buna göre katılımcılar birleşik sağlık uyarılarını, sadece yazıı olan sağlık uyarılarına göre daha etkili, korkutucu ve ikna edici bulduklarını ifade etmişlerdir. Ancak araştrmada, sigara içmeyi bırakmaya yönelik tutum açısından yazıı ve birleşik sağlık uyarılarının birbirlerinden farklı olmadığı ortaya konulmuştur.

Sigara birleşik sağlık uyarıları üzerinde Türkiye'de yapılan çalışmaların uluslararası literatürdeki bulguları destekler nitelikte olduğu görülmektedir. Lise öğrencileri üzerinde yapttkları araştırmada Özkaya vd. (2009) sigarada bulunan uyarıların etkinliğini değerlendirmiştir; araştırmada, sigara içenlerin \%22,5'i birleşik sağıı uyarılarını okuduktan sonra sigarayı bıraktıklarını, \% 44,4'ü yazılardan etkilendiklerini ancak bırakamadıklarını, \%33,1'i ise hiç etkilenmeyerek sigara içmeye devam ettiklerini ifade etmişlerdir. Marmara Üniversitesi Tıp Fakültesi'nde gerçekleştirilen başka bir çalışmada ise, sigara bağımlısı katılımcıların \% 40'ı birleşik sağlık uyarılarının çok etkili olmadığı yönünde görüş bildirmiştir. Ayrıca katılımcıların çoğunluğu uyarıları anlamsız ve yararsız bulduklarını ifade etmişlerdir (Önsüz vd., 2009). Bu bulgular sigara içmenin sonuçlarını gösteren birleşik uyarıların yeterli seviyede etkili olmayabileceğini göstermektedir. Benzer şekilde sigara içenlerin bazıları pakette bulunan birleşik sağlık uyarılarını kapatmaya çalışmakta; bazıları ise satın alma noktalarında kendilerini rahatsı eden sağlık uyarıları yerine başka görsel içeren paketleri istemektedir (Hammond vd., 2004). Birleşik sağlık uyarılarının sigara içenler tarafindan görmezden gelinmesi, görsellerin genel anlamda etkinliği açısından bir problem teşkil etmektedir.

Sigara birleşik sağlık uyarılarını inceleyen diğer önemli çalışma Lindstrom ve Underhill'in (2010) araştırmasıdır. Bu çalışmaya göre, denekler sigarada bulunan sağılı uyarılarından etkilendiklerini söylemelerine rağmen bu durum gerçeği yansıtmamaktadır. Nöropazarlama yöntemlerinden olan fMRI (işslevsel Manyetik Rezonanslı Görüntüleme) ve SST (Sabit Hal Tipografisi) tekniklerinin kullanıldığı araştırmada, yazarlar, birleşik sağılı uyarılarının kişilerin sigarayı daha çok arzulamasına sebebiyet verdiğini ortaya koymuştur.

Literatürde sigara sağlık uyarılarının sigara içmeye karşı negatif tutum geliştirme anlamında etkili olduğunu ifade eden araştirmalar da mevcuttur. Bu kapsamda, Veer ve Rank (2012) sağılık açısından kötü sonuçları gösteren birleşik sağlık uyarılarının sigaranın zararlarına olan farkındalığı arttırdığını ifade etmişlerdir. Mazlum ve Mazlum (2014) ise sigara paketleri üzerindeki birleşik uyarıların üniversite öğrencileri üzerinde etkili olduğunu ve uygulamanın devam ettirilmesinin gerekliliğini belirtmişlerdir.

Sigara birleşik sağlık uyarılarının etkinliği konusunda elde edilen çelişkili bulguların kattımcıların birden fazla sebebi olabileceği düşünülmektedir. Öncelikle, sigara içme düzeylerinin sağlık uyarılarının algılanma biçimini etkileyebileceği unutulmamalıdır. Nitekim Park ve Morton'un (2015) çalışması, yüksek miktarda alkol tüketen kişilerin, ürünle ilgili sağlık uyarılarını kendileriyle örtüştürmediğini göstermiştir. Buna göre sağlığa zararlı bir ürünün kullanım seviyesi arttıkça, ürünle ilgili negatif mesajların inandırıcılığı azalabilmektedir. Amerika Birleşik Devletleri'nde yapılan bir deneyde, üzerinde çeşitli birleşik sağlık uyarıları bulunan sigara paketleri sigara içenler tarafindan değerlendirilmiş, katılımcılardan sigara paketlerine fiyat teklifi vermeleri istenilmiştir. Araştırma sonuçlarında, yaş ve sigara içme düzeylerine göre verilen fiyatların anlamlı bir şekilde farklı olduğu görülmüştür. Buna göre, yaşları küçük olan ve çok sigara içen bireylerin sigaralara daha yüksek fiyat biçtikleri gözlenmiştir. Bu bulgu, aynı görsellerle uyarılmalarına rağmen, çok sigara içenler ile yaşı küçük olanların, sigara sağlık uyarılarından daha az etkilendiğini göstermiştir (Thrasher, 
Rousu, Hammond, Navarro ve Corrigan, 2011). Paragrafta değinilen konular çerçevesinde $\mathrm{H}_{1}$ ve $\mathrm{H}_{2}$ hipotezleri geliştirilmiştir.

$\mathbf{H}_{1}$ : Sigara birleşik sağlık uyarılarının etkili bulunması ile sigara içme düzeyleri birbirinden bağımsız değildir.

$\mathbf{H}_{2}$ : Sigara birleşik sağlık uyarılarının etkili bulunması ile sigara içen bireylerin yaşı birbirinden bağımsız değildir.

Birleşik sağlık uyarılarının yeterince etkili olmamasının diğer bir sebebinin ise cinsiyet kaynaklı olabileceği düşünülmektedir. Bu kapsamda, ülkemizde özellikle erkekler arasında bazı durumlarda sağlığa yeterince önem verilmediği görülmektedir. Türkiye'de yapılmış toplumsal deneyler ve yüz yüze görüşmeler bu gerçeği gözler önüne sermektedir. AIDS gibi ölümcül sonuçları olan hastalıklar için bile bazı vatandaşlarımız, yaptıkları işin sağlık açısından riskleri anlatıldığında, "atın ölümü arpadan olsun"; " ölüm Allah'ın emri, az ileride kaza yapıp ölmeyeceğimi kim garanti edebilir ki?; "biz Türküz bize bir şey olmaz" diyebilmektedir (Biber, 2013). Benzer şekilde Finlandiya, Hollanda ve İngiltere'den katlımcıların olduğu bir araştırma, sağlıklı beslenme konusunda kadın ve erkeklerin aynı seviyede duyarlı olmadığını göstermiştir. Buna göre, gıdaların organik olması, az kalori ve yağ içermesine kadınlar erkeklere göre daha çok dikkat etmektedir (Roinien, Tuorila, Zandstra, Graaf, Vehkalahti ve Stubenitsky, 2001). Aynı şekilde, hayvansal gıdalar üzerinde yapılan başka bir araştırma, kadınların tuz oranı azaltıımış etleri sağlıklı olması açısından erkeklere göre daha çok tercih etme eğiliminde olduğunu göstermiştir (Guardia, Guerrero, Gelapert, Gou ve Arnau, 2006). Bu bulgular, kadınların sağlık anlamında erkeklere göre daha duyarlı davranabildiğini göstermektedir. Benzer şekilde, sigara birleşik sağlık uyarılarının etkinliğini cinsiyete göre değişebileceği; kadınların birleşik sağlık uyarılarından erkeklere oranla daha fazla etkilenebileceği düşünülmektedir (Tuğrul, 2015). Belirtilen bu bulgular çerçevesinde, bu araştırmada sigara sağlık uyarılarının etkinliğinin cinsiyetten bağımsız olup olmadığı irdelenecektir.

$\mathbf{H}_{3}$ : Sigara birleşik sağlık uyarılarının etkili bulunması ile cinsiyet birbirinden bağımsız değildir.

\section{Araşttrmanın Metodolojisi}

\subsection{Araştırmanın Amacı Ve Kapsamı}

Tanımsal nitelikte olan bu araştırma, hâlihazırda sigara paketlerinde bulunan 14 birleşik sağlık uyarısının etkinliğini incelemeyi amaçlamaktadır. Bu sayede, hangi sağlık uyarılarının katılımcılar açısından etkili veya etkisiz görüldüğünün ve sebeplerinin anlaşılması istenmektedir. Araştırmanın bir diğer amacı ise, birleşik sağlık uyarılarının algısının demografik değişkenler açısından değerlendirilmesidir. Böylece cinsiyet, yaş ve sigara içme düzeylerine göre birleşik sağlık uyarılarının etkili bulunma durumunun değişip değişmeyeceği tespit edilecektir. Böylece, sosyal pazarlama kapsamında, doğru kişilere doğru içeriğe sahip sağlık mesajlarının verilmesine dönük temel bilgiler elde edilecektir.

\subsection{Araştırmanın Örneklemi}

Araşttrmanın verisi tesadüfi olmayan yöntemlerden olan kolayda örneklemi yöntemiyle i̇nternet üzerinde toplanmıştır. Bu kapsamda, docs.google.com'da anket formu hazırlanmış ve Facebook üzerinden 17.11.2016 - 24.11.2016 tarihleri arasında paylaşıımıştır. Çok sayıda kişiye ulaşmak için Facebook'un sağlamış olduğu ücretli paylaşım hizmetinden faydalanılmıştır. Bu sayede verilen 67 TL'lik ücret karşılığında Facebook 6842 kişiye erişilmesini sağlamıştr. Bunun yanı sıra Facebook ve Twitter üzerinden yapılan kişisel paylaşımlarla da daha çok katılımcıya ulaşılmaya çalışımıştı. Ancak, İnternet üzerinden veri toplamada en sık karşılaşılan problemlerden bir tanesi düşük cevaplama oranlarıdır (McPeake, Bateson ve O'Neill, 2014). Bu bakımdan, erişilen kişi sayısının çokluğuna rağmen araştırmaya sadece 356 kişi katılım göstermiştir. Ayrıca, eksik ve hatalı anketlerin elenmesiyle birlikte geçerli anket formu sayısı 344 olmuştur.

\subsection{Veri Toplama Yönetimi Ve Aracı}

Araştırmada öncelikle, 14 birleşik sağlık uyarısının katlımcılar tarafindan değerlendirilmesi istenilmiştir. Bu kapsamda, katılımcılardan, sigara içmeyi önleme açısından etkili bulduğu görselleri 
işaretlemeleri; etkili olduğunu düşünmedikleri uyarıları ise boş bırakmaları istenilmiştir. Etkili olarak algılanan görseller " 1 " etkili bulunmayan görseller ise " 0 " olarak kodlanmıştır. Ayrıca anket formunda, açık uçlu soru yardımıyla, katılımcılardan en etkili ve etkisiz bulduğu iki görseli söyleyerek nedenlerini belirtmeleri istenmiştir. Bu sayede, katılımcıların sigara birleşik sağlık uyarıları hakkındaki genel algı ve yorumları daha sonraki araştırmalara yol göstermesi adına keşifsel bir yaklaşımla öğrenilmiştir.

Araştırmada son olarak, örnekleme ilişkin demografik sorular sorulmuştur. Bu kısımda katılımcıların cinsiyeti, eğitim seviyesi, yaşı ve sigara içme düzeyleri hakkında bilgi edinilmiştir. Katlımcıların eğitim seviyesi “i. lise dengi ve alt, ii. ön lisans ve lisans; lisansüstü" olmak üzere 3 kategori olarak değerlendirilmiştir. Sigara içme düzeyleri "i. hiç kullanmadım, ii. önce içiyordum ama artkk kullanmıyorum, iii. arada sırada kullanıyorum, iv. hergün kullanıyorum" olmak üzere 4 kategoriden oluşmaktadır. Son olarak katılımcıların yaş aralıkları "1519; 20-24; 25-29; 30-34 ile 35 ve üstü" olarak 5 grup olarak ölçümlenmiştir.

\subsection{Araştırmanın Kısıtları}

Araşttrmanın en önemli kısıdı, verinin sadece Internet üzerinden toplanmış olmasıdır. Ayrıca, veri toplama esnasında tesadufi olmayan yöntemlerden olan kolayda örnekleme yöntemi tercih edilmiştir. Bu bakımdan, araştırma bulgularının genellenmesinde bir takım sıkıntılar olabileceği için araştırma bulgularının dikkatli bir şekilde yorumlanması tavsiye edilmektedir.

\section{Araştırma Bulguları}

\subsection{Katılımcıların Demografik Özellikleri}

Katılımcıların en büyük grubunu 101 kişinin katılımıyla 25-29 yaş aralığındaki kişiler oluşturmaktadır. Ayrıca erkek katılımcılar 161 kişi iken kadın katılımcıların 183 kişi olduğu görülmüştür. Eğitim düzeyi bakımından ise lisansüstü seviye eğitime sahip katılımcılar 181 kişi ile en büyük grubu oluşturmaktadır (Bakınız Tablo 1).

Katılımcıların sigara içme durumları ise şu şekildedir: "i. hiç sigara kullanmamış olanlar 143 kişi, ii. önceden kullanmış olup ama artk kullanmayanlar 40 kişi, iii. her gün sigara kullananlar 102 kişi, iv. arada sırada kullananlar 59 kişi."

Tablo 1. Katılımcıların Demografik Özellikleri

\begin{tabular}{|c|c|c|c|c|c|c|c|}
\hline & & $\mathbf{1 5 - 1 9}$ & $\mathbf{2 0 - 2 4}$ & $\mathbf{2 5 - 2 9}$ & $\mathbf{3 0 - 3 4}$ & $\mathbf{3 5}$ ve üstü & Ana Toplam \\
\hline \multirow{4}{*}{ Erkek } & Lise dengi ve altı & 5 & 0 & 0 & 0 & 5 & 10 \\
& Ön lisans / lisans & 2 & 19 & 13 & 18 & 12 & 64 \\
& Lisansüstü & 1 & 8 & 33 & 26 & 19 & 87 \\
& Toplam & 8 & 27 & 46 & 44 & 36 & 161 \\
\cline { 2 - 8 } & Lise dengi ve altı & 11 & 1 & 0 & 1 & 3 & 16 \\
\multirow{3}{*}{ Kadın } & Ön lisans / lisans & 5 & 29 & 14 & 11 & 14 & 73 \\
& Lisansüstü & 0 & 14 & 41 & 25 & 14 & 94 \\
& Toplam & 16 & 44 & 55 & 37 & 31 & 183 \\
\hline \multicolumn{2}{|c|}{ Ana Toplam } & $\mathbf{2 4}$ & $\mathbf{7 1}$ & $\mathbf{1 0 1}$ & $\mathbf{8 1}$ & $\mathbf{6 7}$ & $\mathbf{3 4 4}$ \\
\hline
\end{tabular}

\subsection{Frekans Analizi Ve Tanımsal İstatistikler}

Analizlerde önce etkili ve etkili olmayan görseller frekanslara bakarak belirlenmiş; cinsiyet, yaş ve sigara içme düzeyi ile seçilen görseller arasında bir ilişki olup olmadığı Ki-kare analizi ile test edilmiştir. Araştırmada, etkili görseller belirlenirken katılımcıların yarısı veya daha fazlasının etkili olarak algıladığı görseller değerlendirilmiştir. 14 uyarı arasından katılımcılar tarafindan en etkili bulunan birleşik sağlık uyarıları sırasıyla " 3 , 4, 5" numaralı görseller olmuştur. Buna göre, sigara içmiş bir kişinin akciğerini gösteren birleşik sağlık uyarısı (Uyarı 3) en etkili bulunan görsel olarak değerlendirilmiştir. Sonrasında, kuvözde 
müşahede altında tutulan bebek (Uyarı 4) ile solunum makinesine bağlanmış çocuk görseli (Uyarı 5) bulunan birleşik uyarılar katılımcılar tarafindan etkili birleşik sağlık uyarıları olarak değerlendirilmiştir (Bakınız Tablo 2).

Buna karşın, “6, 10, 7, 8, 12" numaralı birleşik uyarılar, katlımcıların ortalama \% 10'u tarafindan etkili bulunmuştur. Bu açıdan belirtilen görsellerin katılımcılar nezdinde yeterince etkin olarak algılanmadığı düşünülmektedir.

Tablo 2. Birleşik Sağlık Uyarı Görsellerinin Etkili Bulunma Frekansları

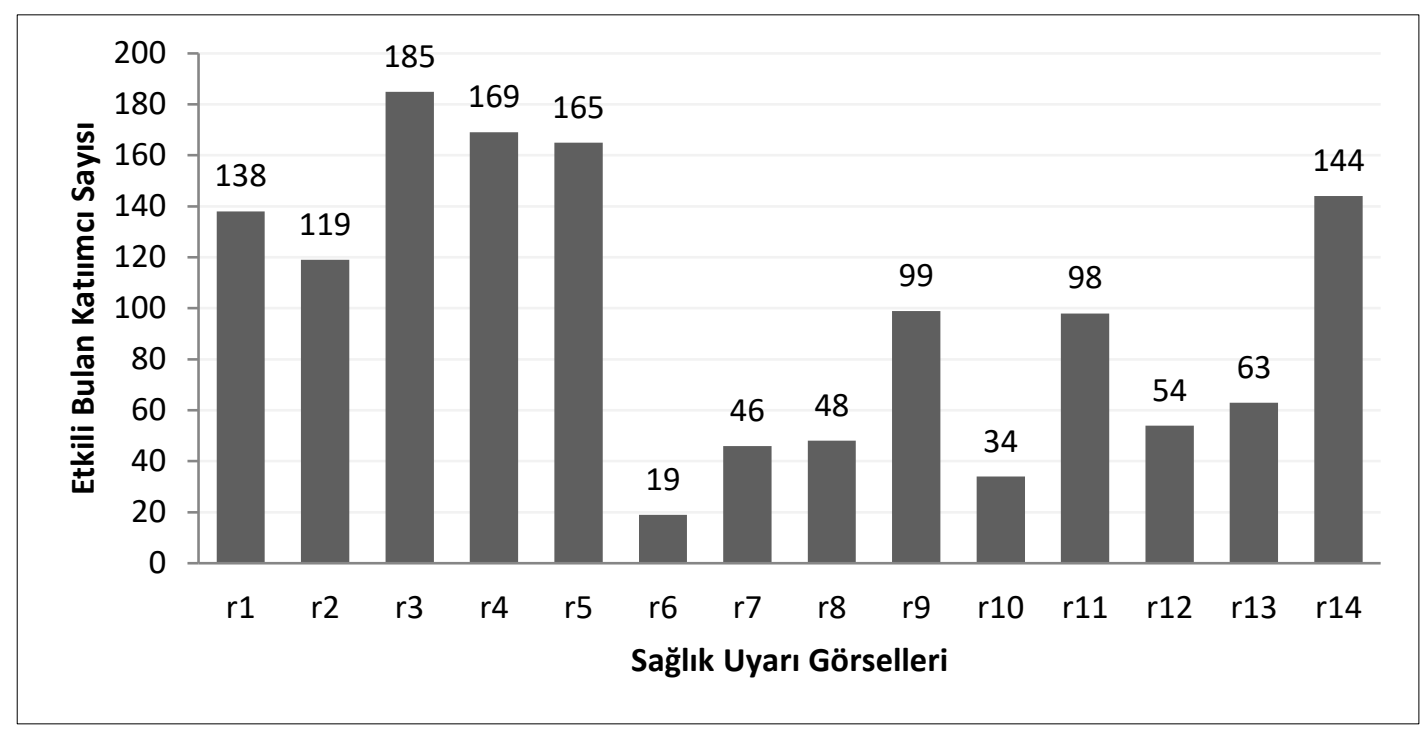

Etkili olan birleşik sağlık uyarılarının tespit edilmesiyle ki-kare bağımsızlık testi uygulanarak etkili bulunan uyarılar ile demografik değişkenler arasında bir ilişki olup olmadığı incelenmiştir. Ki-kare bağımsızlık testi iki veya daha fazla değişken grubu arasında bağımlılık olup olmadığını test etmek için kullanılan parametrik olmayan bir yöntemdir (Kalaycı, 2010). Araştırmada sırasıyla sigara içme düzeyleri, cinsiyet ve yaş ile etkili bulunan sağlık uyarıları arasında bir ilişkinin olup olmadığı test edilmiştir.

Analizlerde, sigara içme düzeyi ile en etkili bulunan ilk 3 birleşik sağlık uyarısının $(3,4,5$ numaralı sağlık uyarıları") etkili olarak algılanma durumunun birbirinden bağımsız olma durumu test edilmiştir. Bu kapsamda öncelikle ki-kare tablosundaki hücrelerin frekanslarına bakılmış en az frekans bulunan hücrede 14 gözlem olduğu tespit edilmiştir (Bakınız Tablo 3). Bağımsızlık testi sonuçlarına göre 3 numaralı birleşik sağlık uyarısının etkinliğinin sigara içme düzeyinden bağımsız olduğu görülmüştür (Pearson $\chi 2: 2.640 ;$ p. 0.450). Buna karşın, 4 numaralı uyarıda bulunan kuvözde yatan bebek görseli (Pearson $\chi 2$ : 10.036; p. 0.018) ile 5 numaralı uyarıdaki solunum makinesine bağlanmış ufak çocuk (Pearson $\chi 2$ : 16.815; p. 0.001) görsellerinin algısı ile sigara içme düzeyi arasında bir ilişki olduğu gözlenmiştir. Buna göre, sigara içme seviyesi azaldıkça birleşik sağıı uyarıları daha fazla katılımcı tarafından etkili olarak değerlendirilmiştir. Ancak, sigara içme düzeyi arttkķ̧a, birleşik sağlık uyarıları daha az katılımcı tarafindan etkili bulunmuştur. Bu bulgu, çocuk sağlığı gibi önemli bir konuda sigara kullananların duyarsız davranıyor olabileceğini göstermektedir. Bu durumun katılımcıların bağımlılık seviyelerinden kaynaklanabileceği düşünülmektedir. Çünkü, bağımlıık arttıkça, kişiler ürünle ilgili sağlık uyarılarını kendileriyle örtüştürmeyerek (Park ve Morton, 2015) verilen mesajları göz ardı etmeye çalışmaktadır (Önsüz vd., 2009). Ki-kare analizi bulguları ışığında $\mathrm{H}_{1}$ hipotezi $\left(\mathrm{H}_{1}\right.$ : sigara içme düzeyi ile birleşik sağlık uyarılarının etkili bulunması birbirinden bağımsız değildir) değerlendirilmiş ve $\mathrm{H}_{1}$ hipotezinin kabul edilebileceği düşünülmüştür. Çünkü sigara içme düzeyinden bağımsız olmadığı görülen 4 ve 5 numaralı birleşik sağlık uyarıları, kathlımcıların büyük çoğunluğu tarafından etkili bulunmuş olan görsellerdir. 
Tablo 3. Sigara İçme Düzeyleri Ile Birleşik Sağlık Uyarılarının Etkili/Etkisiz Bulunma Durumlarına Göre Gözlem Sayıları

\begin{tabular}{|l|c|c|c|c|c|c|c|c|}
\cline { 2 - 9 } \multicolumn{1}{c|}{} & \multicolumn{3}{c|}{3 Nolu Uyarı } & \multicolumn{2}{c|}{ 4 Nolu Uyarı } & \multicolumn{2}{c|}{5 Nolu Uyarı } & \multirow{3}{*}{} \\
\cline { 2 - 9 } \multicolumn{1}{c|}{} & Etkisiz & Etkili & Etkisiz & Etkili & Etkisiz & Etkili & Toplam \\
\hline Hiç içmemiş olanlar & 67 & 76 & 60 & 83 & 57 & 86 & 143 \\
\hline Önceden içmiş olup şimdi kullanmayanlar & 14 & 26 & 25 & 15 & 25 & 15 & 40 \\
\hline Arada Sırada Içenler & 27 & 32 & 29 & 30 & 31 & 28 & 59 \\
\hline Hergün İçenler & 51 & 51 & 61 & 41 & 66 & 36 & 102 \\
\hline Toplam & 159 & 185 & 175 & 169 & 179 & 165 & $\mathbf{3 4 4}$ \\
\hline
\end{tabular}

Analizlerde değerlendirilen diğer bir hipotez, "Sigara birleşik sağılı uyarılarının etkili bulunması ile sigara içen bireylerin yaşı birbirinden bağımsız değildir" hipotezidir $\left(\mathrm{H}_{2}\right)$. Bu çerçevede, yapılan ki-kare analiziyle etkili bulunan birleşik sağlık uyarılarının frekansları ile yaş grubu frekansları arasındaki ilişki test edilmiştir. Ayrıca ki-kare tablosu oluşturulmuş, bütün gözlemlerin $5^{\prime}$ den fazla frekansa sahip olduğu görülmüştür (Bakınız Tablo 4). Etkili bulunma anlamında en çok frekansa sahip olduğu için öncelikle 3 numaralı uyarı değerlendirilmiştir. Ki-kare testinde 3 numaralı birleşik sağlık uyarısının etkili görülmesinin katılımcıların yaş grubundan bağımsız olduğu görülmüştür (Pearson х2: 6.082; p. 0.193). Sonrasında diğer iki birleşik sağıık uyarısı ile katlımcıların yaşı arasındaki ilişki incelenmiş, ancak yine herhangi bir ilişki bulunamamıştır (4. uyarı için "Pearson X2: 6.680, p. 0.154" ; 5 . uyarı için "Pearson X2: 2.871; p. 0.580) Bu bakımdan $\mathrm{H}_{2}$ hipotezi reddedilerek sıfir hipotezi kabul edilmiştir. Yani sigara içen bireylerin yaşıyla, sigara birleşik sağlık uyarılarının etkili bulunmasının birbirinden bağımsız olabileceği düşünülmüştür.

Tablo 4. Yaş Aralığı ile Birleşik Sağlık Uyarılarının Etkili/Etkisiz Bulunma Durumuna Göre Gözlem Sayıları

\begin{tabular}{|l|c|c|c|c|c|c|c|}
\cline { 2 - 7 } \multicolumn{1}{c|}{} & \multicolumn{2}{c|}{3 Nolu Uyarı } & \multicolumn{2}{c|}{ 4 Nolu Uyarı } & \multicolumn{2}{c|}{5 Nolu Uyarı } & \multirow{2}{*}{} \\
\cline { 2 - 7 } \multicolumn{1}{c|}{} & Etkisiz & Etkili & Etkisiz & Etkili & Etkisiz & Etkili & Toplam \\
\hline $15-19$ & 15 & 9 & 15 & 9 & 14 & 10 & 24 \\
\hline $20-24$ & 36 & 35 & 43 & 28 & 38 & 33 & 71 \\
\hline $25-29$ & 46 & 55 & 47 & 54 & 57 & 44 & 101 \\
\hline $30-34$ & 38 & 43 & 35 & 46 & 40 & 41 & 81 \\
\hline 35 ve üstü & 24 & 43 & 35 & 32 & 30 & 37 & 67 \\
\hline Toplam & 159 & 185 & 175 & 169 & 179 & 165 & $\mathbf{3 4 4}$ \\
\hline
\end{tabular}

Araştırmada değerlendirilen son hipotez; "sigara birleşik sağlık uyarılarının etkili bulunması ile cinsiyetin birbirinden bağımsız olması" durumudur. Bu kapsamda ki-kare analiziyle, üç birleşik sağlık uyarısı birkez daha değerlendirilmiştir. Ki-kare tablosunda bütün hücrelerde gözlem sayısı 5'ten daha fazladır (Bakınız Tablo 5). Analizlerde 3. uyarının etkili bulunma durumuyla, cinsiyet arasında bir ilişki bulunmadığı gözlenmiştir (Pearson x2: 1.378; p. 0.241). Buna karşın 4. uyarının etkili bulunma durumuyla cinsiyet arasında güçlü bir ilişki bulunmaktadır (Pearson $\chi 2: 15.298 ;$ p. 0.000). Buna göre erkeklere göre daha fazla oranda kadın katılımcı, 4 numaralı birleşik sağlık uyarısını etkili bir uyarı olarak değerlendirmiştir. Erkekler ise kadınlara oranla 4. resmi daha az etkili bulmuşlardır. Benzer bir bulgu, 5. uyarı için de tespit edilmiştir (Pearson X2: 4.890; p. 0.027). Kadın katlımcılar daha büyük bir oranla 5. birleşik sağlık uyarısının etkili olduğu konusunda görüş bildirmişlerdir. Erkekler ise kadınlara oranla daha az sayıda bu sağlık uyarısını etkin bulmuşlardır. Ki-kare analizi sonuçları genel olarak değerlendirildiğinde, $\mathrm{H}_{3}$ kabul edilmiştir. Buna göre cinsiyet ile etkili bulunan birleşik sağlık uyarılarının birbirinden bağımsız olmayabileceği kabul edilmiştir. 4 ve 5 numaralı sağlık uyarılarında ortak nokta her ikisinde de çocuk sağlığının ön planda tutulmuş olmasıdır. Buna göre kadınlar, belki annelik içgüdüleri, belki de toplumun ve kültürün kendilerine yüklemiş olduğu annelik rolünden dolayı çocukların sağlık problemlerini içeren uyarılardan daha fazla etkilenmişlerdir. Ancak erkekler, bu görsellerden kadınlara oranla daha az etkilenmiş gözükmektedirler. Bu bulgu, kadınlara ve erkeklere 
yönelik yapılan sigara karşıt reklam kampanyalarında çocuk figürünün birbirinden farklı algılanabileceğini göstermektedir. Bu bakımdan, sigara paketlerinde özellikle kadınların tüketmiş olduğu markaların tespit edilmesi ve bu ürünlerde çocuk görseli bulunan birleşik sağlık uyarılarının daha fazla kullanılmasının daha etkili olabileceği düşünülmektedir.

Tablo 5. Cinsiyet İle Birleşik Sağlık Uyarılarının Etkili/Etkisiz Bulunma Durumuna Göre Gözlem Sayıları

\begin{tabular}{|c|c|c|c|c|c|c|c|}
\hline & \multicolumn{2}{|c|}{3 Nolu Uyarı } & \multicolumn{2}{|c|}{4 Nolu Uyarı } & \multicolumn{2}{|c|}{5 Nolu Uyarı } & \multirow[b]{2}{*}{ Toplam } \\
\hline & Etkisiz & Etkili & Etkisiz & Etkili & Etkisiz & Etkili & \\
\hline Erkek & 69 & 92 & 100 & 61 & 94 & 67 & 161 \\
\hline Kadın & 90 & 93 & 75 & 108 & 85 & 98 & 183 \\
\hline Toplam & 159 & 185 & 175 & 169 & 179 & 165 & 344 \\
\hline
\end{tabular}

Bu çalışma, yaş, cinsiyet ve sigara içme düzeyine göre birleşik uyarıların etkili bulunma seviyesinin değişebileceğini göstermiş olsa da, bu ilişkiler sadece 3 birleşik uyarı yardımıyla test edilmiştir. Bunun temel sebebi, araştırmanın sadece etkili bulunan görseller üzerinden yola çıkmış olmasıdır. Ancak, bu yaklaşım etkili bulunmayan birleşik uyarılarında nasıl bir ilişki olduğu konusunun incelenmediği anlamına gelmektedir. Bu bakımdan, ki-kare testi sonuçlarının bütün sağlık uyarılarına genellenmesinde bir takım sıkıntılar olabileceği; sonraki araştrmalarda diğer görsellerin incelenmesinin literatüre önemli katkılar sağlayacağı düşünülmektedir.

Araştırmada ayrıca, frekans analizi ve açık uçlu sorulara verilen cevaplar da (kalitatif bulguların tamamı Ek'te bulunmaktadır.) incelenmiştir. Bu kapsamda sırasıyla, etkili olduğu düşünülen "3, 4, 5, 14 ve 1" numaralı birleşik sağlık uyarılarıyla etkisiz bulunan ilk 5 birleşik sağlık uyarısı $(6,10,7,8,12)$ incelenmiş; kathlımcıların görseller hakkındaki görüşleri değerlendirilmiştir. Katlımcıların yorumları değerlendirildiğinde; doğrudan sigaranın sonucu olarak algılanan sağlık problemlerini anlatan mesajların daha etkili olduğu görülmüştür. Buna göre, sigara içen ve içmeyen kişilerin akciğerlerini karşılaştıran 3. birleşik sağlık uyarısı en etkili uyarı olarak değerlendirilmiştir. Buna karşın, genç yaşta ölme temalı 1. birleşik sağlık uyarısı ile genç bir hastanın yoğun bakımda olduğu 14. birleşik sağlık uyarısı katlımcılar tarafindan daha az etkili olarak algılanmıştır. Çünkü, katlımcılar herkesin genç yaşta ölebileceğini ifade ederek morg resmini abart ve gerçekçi olarak görmediklerini ifade etmişlerdir. Ayrıca, birleşik sağlık uyarılarında herkesin anlayabileceği somut ve sade bir dil kullanılmasının daha etkili olacağı düşünülmektedir. Birleşik sağlık uyarılarının çok teknik ve tıbbi terimler içermesi zor anlaşılmasına neden olmaktadır. Bu açıdan, birleşik sağlık uyarılarında, sade ve anlaşılabilir bir mesajla, ölümden ziyade doğrudan sigarayla ilişiklendirilebilecek birleşik sağıık problemlerinin tasvir edilmesinin daha faydalı olacaktır. Bazı katılımcılar ise birleşik birleşik sağlık uyarılarında insan çehresi kullanılmasının daha etkili olduğunu ifade etmişlerdir. Buna göre; 1. ve 14. uyarılar kişilerin kendini görselde bulunan bireylerin yerine koyabilmesi ve hayal edebilmesi açısından etkili olarak değerlendirilmiştir. Ancak, daha öncede belirtildiği gibi ölüm herkesin yaşayacağı bir sondur; bu bakımdan doğrudan ölüm temasının kullanılması bazı katılımcılar tarafindan birleşik birleşik sağlık uyarısının yeterince etkili olarak algılanmamasına neden olacaktır.

Bulgularda dikkat çeken bir diğer önemli nokta, çocuk (5. birleşik sağlık uyarısı) ve bebek (4. birleşik sağıık uyarısı) görsellerinin özellikle kadınlar arasında oldukça etkili olduğudur. Kadınların sosyal ve biyolojik rollerinin, bu sonuca doğrudan bir etkisinin olabileceği düşünülmektedir. Ancak sigara içme düzeyinin artmasıyla daha az sayıda katılımcı 4. ve 5. birleşik sağıık uyarılarını etkili olarak algılamıştır. Çünkü literatür kısmında değinildiği üzere, bağımlıık düzeyi arttkç̧a birleşik sağlık uyarılarının kabul edilebilirliği bazen azalabilmektedir.

Etkili bulunan görsellerden sonra etkili olarak değerlendirilmeyen görseller incelenmiştir. 6 ve 10 numaralı birleşik uyarılar sigarayı bırakmak isteyenlere sağlık ocakları ve doktorlardan yardım alabileceklerini anlatmaktadır. Ancak, katlımcıların büyük bir çoğunluğu Türkiye'de, sigara bırakma konusunda sağlık kuruluşlarından destek alabileceklerine inanmadıklarını belirtmişlerdir. Örneğin bir katılımcı "kendim de bir sağ ık çalışanı olarak sağlık kuruluşlarının bu anlamda yeterli olduğunu düşünmüyorum." diyerek bu uyarıların 
ne kadar etkisiz algılandığını göstermiştir. Ayrıca her iki uyarı için de katılımcılar; sadece görsele bakınca bir şey anlayamadıklarını, yazılı ve görsel uyarı arasında bir bağ kuramadıklarını belirtmişlerdir. Bu durum birbirinden ayrılan eller görseli olan 10 numaralı birleşik sağlık uyarısı için de geçerlidir. Bu kapsamda, bir katılımcı bu sağlık uyarısı hakkında, "fotoğraf saçma geldi; olumsuz değil olumlu bir görsel gibi algılanıyor." şeklinde görüş belirtmiştir.

Katılımcılar tarafindan etkisiz bulunan diğer birleşik sağlık uyarıları 7, 8 ve 12 numaralı uyarılardır. 7 nolu uyarı hakkında katılımcılar; "sigaranın hapsetme meselesi çok psikolojik ve soyut olduğu için resim yeterli değil." ve "metni okumasam bir şey ifade etmiyor" şeklinde görüş bildirmişlerdir. Benzer şekilde, 8 nolu uyarının görseli, sağlık sorunu yaşayan bir kişiden çok koşu bandında spor yapan bir kişi olarak algılanmıştır. Bu açıdan sağlık uyarısında verilmek istenen mesaj tam olarak anlaşılamamıştır. Son olarak, sigaranın cilt kırışıklığına sebep olduğunu anlatan 12 nolu uyarı da yeterince etkili olarak değerlendirilmemiştir. Bu kapsamda katılımcıların büyük bir çoğunluğu, cilt kırışıklığını önemli bir problem olarak görmediklerini; er ya da geç cildin zaten kırışacağını belirtmişlerdir.

\subsection{Sonuç Ve Değerlendirme}

Araşttrma bulguları, birleşik sağlık uyarılarında kullanılacak görselin ne kadar önemli olduğunu göstermektedir. Buna göre, yoruma açık bir ortam yaratmadan, net ve çarpıcı görsellerin kullanılması birleşik sağık uyarılarının daha etkili olmasını sağlayacaktır. Ayrıca, görsel ve yazıların birbirleriyle tutarlı olması, birleşik sağlık uyarılarının etkinliğini arttran önemli bir faktördür. Bu kapsamda, birleşik sağlık uyarılarının doğrudan sigara içmekle ilişkilendirilen akciğer hastalıkları gibi konulara değinmesi mesajın etkinliğini arttracaktır. Ayrıca, ölüm gibi herkesin başına gelecek sonuçlardansa, daha spesifik uyarıların etkili olarak algılanacağı düşünülmektedir. Son olarak, özellikle kadınların tüketmiş olduğu markalarda çocuk görseli içeren uyarıların kullanılmasının daha faydalı olacağına inanılmaktadır. Bu kapsamda, kadınların içtiği markalar tespit edilerek bu markalarda çocuk görselinin daha yoğun kullanılması tavsiye edilmektedir.

Sigara paketinin ve birleşik sağlık uyarılarının tasarımı toplumsal faydayı amaçladığı için sosyal pazarlamanın ilgi alanına girmektedir. Sigara birleşik sağlık uyarıları tasarlanırken, farklı hedef gruplarına farklı mesaj verilmesinin önemli bir strateji olduğu düşünülmektedir. Bu sayede herkes için standart bir mesajdan ziyade; cinsiyet, yaş, gelir durumu ve tercih edilen markalara göre değişiklik gösteren farklı uyarılar geliştirilebilecektir. Böylece, daha etkili birleşik sağlık uyarılarının tasarlanabileceği düşünülmektedir. Ayrıca, ileriki araştırmaların bu konulara değinmesi; farklı örneklem grupları üzerinde sağlık görsellerinin etkinliğini test etmesi tavsiye edilmektedir.

Bu araştırma, etkili bulunan 3 birleşik uyarıdan yola çıkarak, cinsiyet, yaş ve sigara içme düzeyleri ile görsellerin etkili bulunma durumu arasındaki ilişkiyi incelemiştir. Ancak diğer 11 birleşik uyarı, katıımcıların yarısından daha fazlası tarafindan yeterince etkili bulunmadığı için çalışma kapsamında değerlendirilmemiştir. Bu bakımdan ki-kare analizi bulgularının genellenmesinde dikkatli olunması tavsiye edilmekte ve sonraki araştırmalarda diğer birleşik uyarılarının da incelenmesinin literatüre katkı sağlayacağı düşünülmektedir. Çalışmada ayrıca, her bir birleşik sağlık uyarısı hakkında katılımcıların görüş ve düşünceleri açık uçlu sorular yardımıyla derlenmiştir. Bu yaklaşım, görseller hakkında genel anlamda bir fikir vermiş olsa da görseller hakkında kesin sonuçlar çıkarmak anlamında yeterli değildir. İleriki araştırmalarda, nitel analiz programları sayesinde birleşik sağlık uyarılarına detaylı içerik analizi yapılmasının konunun daha iyi anlaşıımasına katkı sağlayacağı düşünülmektedir.

\section{Kaynaklar}

Bayraktaroğlu, G., \& Illter, B. (2007). Sosyal pazarlama: Engeller ve öneriler. Ege Akademik Bakış, 7(1), 117-132.

Biber, N. (2013). Atn ölümü arpadan olsun. Milliyet Gazetesi, http://blog.milliyet.com.tr/atin-olumu-arpadanolsun/Blog/?BlogNo=439012. Erişim Tarihi, 5 Aralık 2016

Cheron, E. (2015). Effect of graphic ımages in cigarette health warning: A call for stricker packaging regulation in Japan. Journal of International Consumer Marketing, 27, 137-151. 
Sigara Paketlerinde Bulunan Birleşik Sağlık Uyarılarının Etkinliğinin Sosyal Pazarlama Açısından Değerlendirilmesi

Ekpu, V., \& Brown, A. (2015). The economic Impact of smoking and of reducing prevalence: Review of evidence. Tobacco Use Insights, 8(1), 1-35.

Green, J., Tones, K., Cross, R., Woodall, J. (2015). Health promotion. London: Sage Publications.

Guardia, M. D., Guerrero, J., Gelapert, J., Gou, P., \& Arnau, J. (2006). Consumer attitude towards sodium reduction in meat products and acceptability of fermented sausages with reduced sodium content. Meat Science, 73, 484490.

Hammond, D., Fong, G., McDonald, P., Browns, S., \& Cameron, R. (2004). Graphic Canadian cigarette warning labels and adverse outcomes: Evidence from Canadian smokers. American Journal of Public Health, 94(8), 1442-1445.

Hassan, L. M., Walsh, G., Shiu, E. M., Hastings, G. and Harris, F. (2007). Modelling persuasion in social advertising: A study of responsible thinking in antismoking promotion in eight Eastern EU member. Journal of Advertising, 36(2), 15-31.

Havanı Koru. (2016). 2016 yılı tütünle mücadele yılı ilan edildi. http://www.havanikoru.org.tr/component/k2/232.html. Erişim Tarihi, 5 Aralık 2016

Kalaycı, Ş. (2010). SPSS uygulamalı çok değişkenli istatistik teknikleri. Ankara: Asil Yayın.

Kim, Y. (2006). The role of regulatory focus in message framing in antismoking advertisements for adolescents. Journal of Advertising, 35(1), 143-151.

Kotler, P., \& Andreasen, A. (1996). Strategic marketing for non profit marketing. Englewood Cliffs: Prentice-Hall,.

Lindstrom, M., \& Underhill, P. (2010). Buyology: Truth and lies about why we buy. Crown Pub: Double Day.

Mazlum, F. S., \& Mazlum, Ö. (2014). Sigara paketlerinin üzerindeki görsel ve sözel uyarı mesajlarının üniversite öğrencileri üzerindeki etkisinin incelenmesi ve yeni öneriler. E-Journal of New World Sciences Academy, 9(1), 12 32.

McPeake, J., Bateson, M., \& O’Neill, A. (2014). Electronic surveys: How to maximise success. Nurse researcher, 21(3), 24-26.

OECD. (2014). Health At a Glance. http://www.oecd.org/els/health-systems/Health-at-a-Glance-Europe-2014CHARTSET.pdf. Erişim Tarihi, 5 Aralık 2016

Önsüz, M. F., Algan, A., Soydemir, E., Aslan, İ., \& Topuzoğlu, A. (2009). Sigara içen hastaların sigara paketlerinin üzerindeki uyarı yazıları hakkındaki görüşlerinin ve nikotin bağımlılık derecelerinin değerlendirilmesi. Marmara Medical Journal, 22(2), 111-122.

Özkaya, Ş., Edinsel, Ş., Özkaya, E., \& Hamzaçebi, H. (2009) Sigara paketleri üzerinde yer alan yeni uyarı yazılarının lise öğrencileri üzerinde etkileri. Tüberküloz ve Toraks Dergisi, 57(3), 327-332.

Park, S. Y., \& Morton, C. (2015). The role of regulatory focus, social distance, and ınvolvement in anti-high-risk drinking advertising: A construal-level theory perspective. Journal of Advertising, 44(4), 338-348.

Resmi Gazete. (2004). Dünya Sağlık Örgütü Tütün Çerçeve Sözleşmesi. http://www.resmigazete.gov.tr/eskiler/2004/12/20041225.htm .Erişim Tarihi, 5 Aralık 2016

Resmi Gazete. (2010), Tütün mamullerinin zararlarından korumaya yönelik üretim şekline, etiketlenmesine ve denetlenmesine ılişkin usul ve esaslar hakkinda yönetmelikte değişiklik yapilmasina dair yönetmelik. http://www.resmigazete.gov.tr/eskiler/2010/02/20100227-8.htm. Erişim Tarihi, 5 Aralık 2016

Roinien, K., Tuorila, H., Zandstra, E. H., Graaf, C., Vehkalahti, K., \& Stubenitsky, K. (2001). Differences in health and taste attitudes and reported behaviour among Finnish, Dutch and British consumers: A cross-national validation of the Health and Taste Attitude Scales (HTAS). Appetite, 33-45.

Tapdk. (2015). Yıllar itibariyle sigara iç satışı. http://www.tapdk.gov.tr/tr/piyasa-duzenlemeleri/tutun-mamulleripiyasasi/tutun-mamulleri-istatistikleri.aspx. Erişim Tarihi, 5 Aralık 2016.

Thrasher, J. F., Rousu, M. C., Hammond D., Navarro A., \& Corrigan, J. R. (2011). Estimating the impact of pictorial health warnings and "plain" cigarette packaging: Evidence from experimental auctions among adult smokers in the United States. Health Policy, 41-48.

Tuğrul, T.O. (2015). The impacts of fear and disgust on the perceived effectiveness of smoking warning labels: a study on Turkish university students. Asia Pacific Journal of Public Health, 27(2), 506-512.

Türkiye Halk Sağlığı Kurumu. (2012). Küresel yetişkin tütün araştırması Türkiye. http://www.halksagligiens.hacettepe.edu.tr/KYTA_TR.pdf. Erişim Tarihi, 5 Aralık 2016.

Uptown, D., \& Thirlaway, K. (2014). Promoting healthy behavior: A practical guide. Routledge 
Veer, E., \& Rank, T. (2012). Warning! the following packet contains shocking ımages: The Impact of mortality saliance on the effectiveness of graphic warning labels. Journal of Consumer Behavior, 11, 225-233.

Weinreich, N. K. (1999). Hands-On social marketing: A step-by-step guide. London: Sage Publications.

World Health Organization. (2015). Tobacco Fact Sheet. http://www.who.int/mediacentre/factsheets/fs339/en/. Erişim Tarihi, 5 Aralık 2016.

World Health Organization. (1986). The Ottowa Charter for Health Promotion. http://www.who.int/healthpromotion/conferences/previous/ottawa/en/. Erişim Tarihi, 15 Nisan 2017 


\section{Ekler}

3 Nolu Birleşik Uyarı

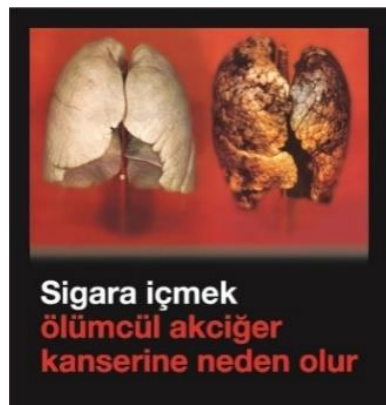

\section{Etkili Görülme Sebepleri}

- Daha somut bir durumu yansıttığından dolayı etkili olduğunu düşünüyorum.

- $\quad$ Sigara büyük oranda ciğerlere zarar veriyor kanısındayım. Dolayısıyla kendimizi ve daha doğmadan çocuklarımızı, geleceğimizi korumalıyız.

- $\quad$ Sağlıklı bir ciğerle sağlıksız bir ciğerin gösterilmesi sigara içen birini en az bir kerede olsa ciddi düşündürebilir.

- $\quad$ Sigara içenlerin ciğerini alenen gösterdiği ve kıyas yaptığı için daha dikkat çekici.

- $\quad$ Sigaranın en fazla zarar verdiği organın bu kadar aleni bir şekilde gösterilmesi çok etkili.

- $\quad$ Akciğer kanseri tedavi edilemez olduğu için bunu gösteren resim de korkutuyor.

\section{Etkisiz Görülme Sebepleri}

- Her yerde çok fazla karşımıza çıktığı için artık ezberlenmiş durumda.

- $\quad$ Yıllardır aynı görseli görüyoruz.

\section{4 ve 5 Nolu Birleşik Uyarılar}

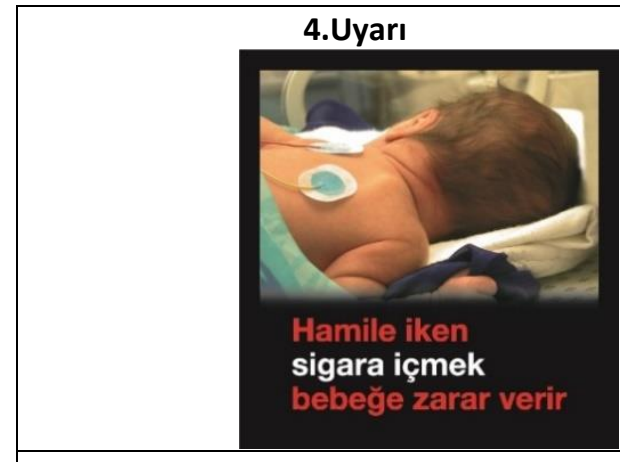

5.Uyarı

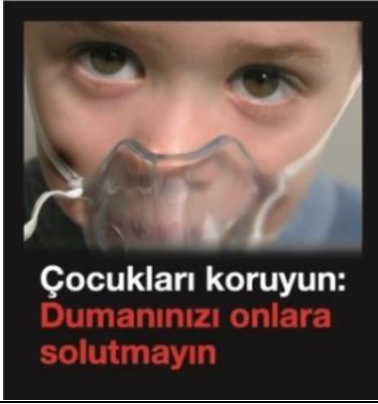

\section{Etkili Görülme Sebepleri}

- $\quad$ Anne olmamdan dolayı etkileniyorum

- $\quad$ Bir bebeğin o durumda olması vicdani bir durumu izhar ettiği için etkili olduğunu düşünüyorum.

- Masum bir canlının sırf bir annenin keyfi nedeni ile zarar görmesi vurgulandığı için çok etkileyici ve üzücü.

- $\quad$ Bir anne için bebeği kendisinden, hatta herkesten her şeyden, sigaradan daha değerlidir.

- $\quad$ Çünkü bizim geleceğimiz çocuklardır. Onlara bu kötülüğü yapmamamız gerektiğine inanıyorum.

- Kadın olmam sebebiyle 4. görsel ileride çocuk sahibi olmayı düşündüğüm için beni çok etkiledi.

- $\quad$ Sigara içen kişilerin \% 99 kendi sağlıklarına olan zararlarını zaten bilmektedir. Ancak çocuklarına da zarar verdiğinin belirtilmesi bence daha etkilidir.

- $\quad$ Sigara kullanan biri olarak çocukların etkilenmemesi gerekir. Hamileyken içmedim ve şu an çocuğumun yanında kullanmıyorum.

- C C C C Socuk sağlığının etkilenme olasılığının bireyin kendi sağlığına yönelik tehlikeden daha etkileyici bir yönü olduğunu düşünüyorum.

- Savunmasız bireylere(çocuklara) zarar verdiğini düşündürüyor. Popüler özgürlük anlayışları bize bireyin davranışlarını başkalarına zarar verip vermediğine göre değerlendirmeyi öğretti. Kişi kendi sağlığına verdiği zararı kanıksıyor ancak bir başkasına hele çocuklara zarar verdiğini düşündüğünde davranışı yeniden değerlendiriyor. Bu yüzden görsel etkili. Ancak bence, bu benim bedenim onu istediğim gibi kullanırım algıSı da yanlış; bu beden bana emanet, onu korumak benim görevim. Bedenim üzerinde istediğim şekilde tasarruf 
edemem algısı acilen gelişmeli.

\section{Uyarı için}

\section{Etkisiz Görülme Sebepleri}

- $\quad$ Erkekler için etkisizdir

- $\quad$ Çocuğu olmayan birisini etkileyeceğini düşünmüyorum

\section{Uyarı için}

- $\quad$ O dumana biz sebep olmasak da başka yerlerde kaçınılmaz şekilde çocuklar kirli havaya maruz kalıyorlar.

- $\quad$ Sigara içen birisi olarak şahsen ben ve bildiğim birçok kişi balkonda dışarıda vs. sigara içmektedir. Evde arabada sigara zaten içilmiyor.

- $\quad$ Çocuğu olmayan birisini etkileyeceğini düşünmüyorum.

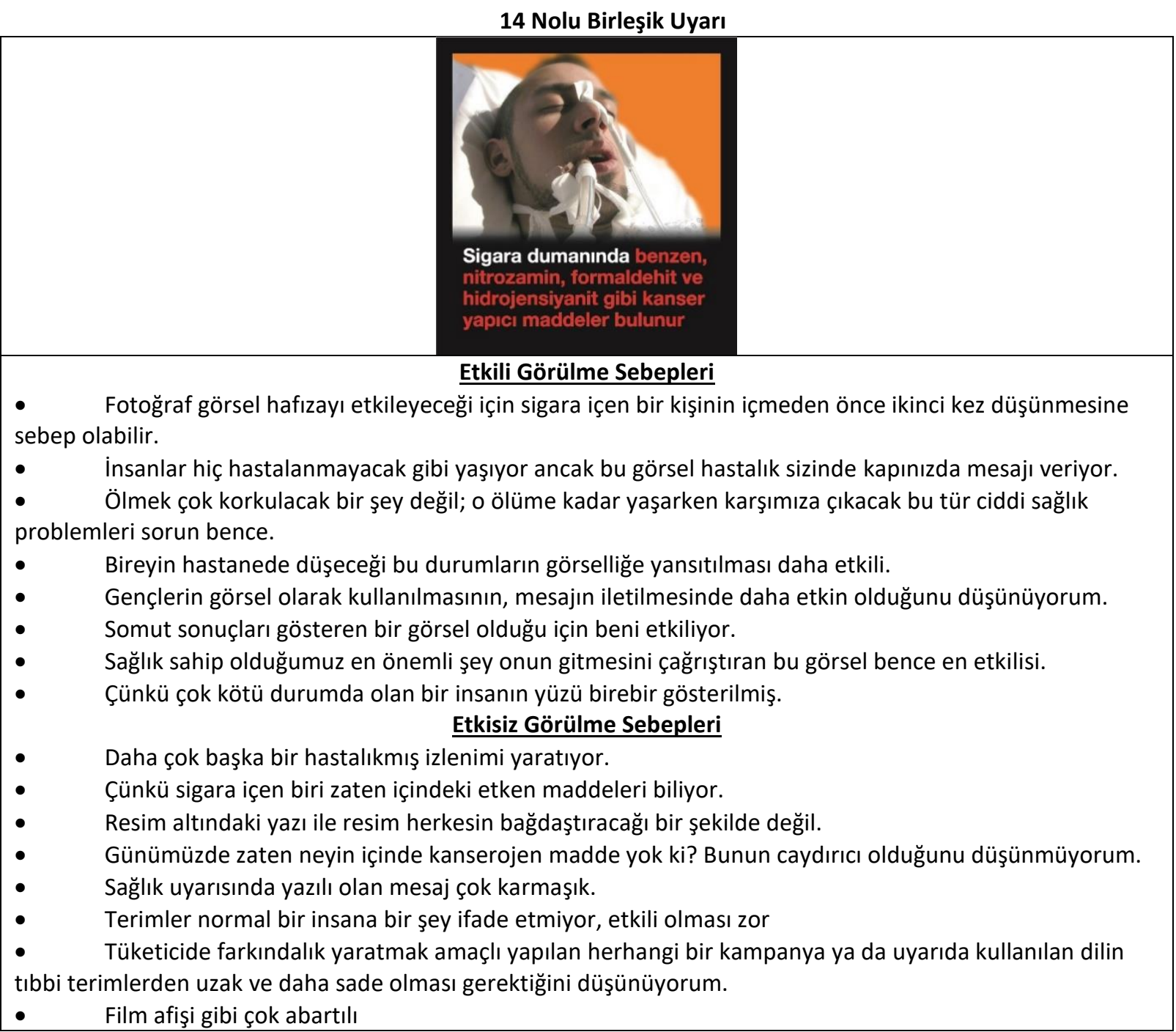




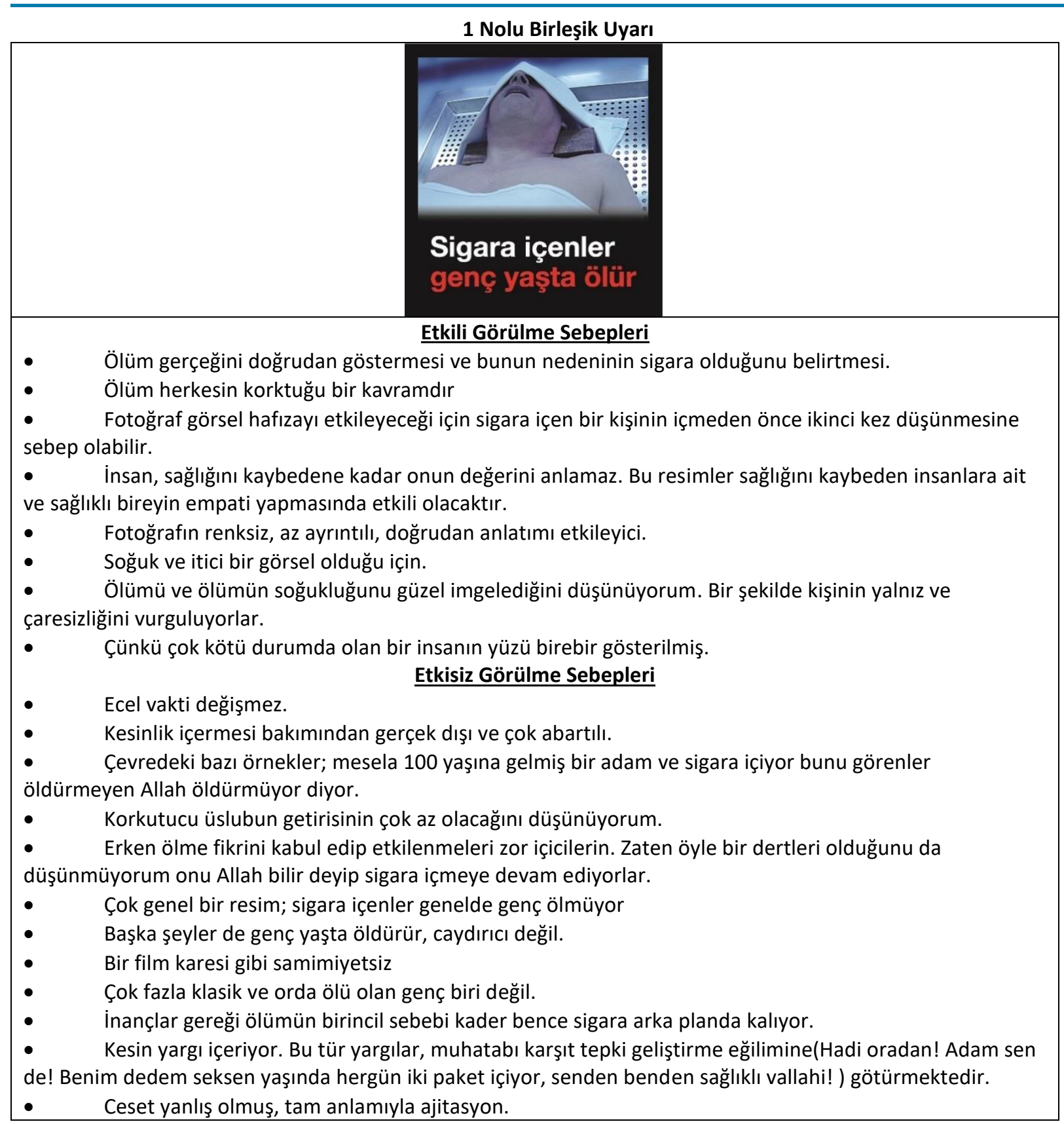

6 Nolu Birleşik Uyarı

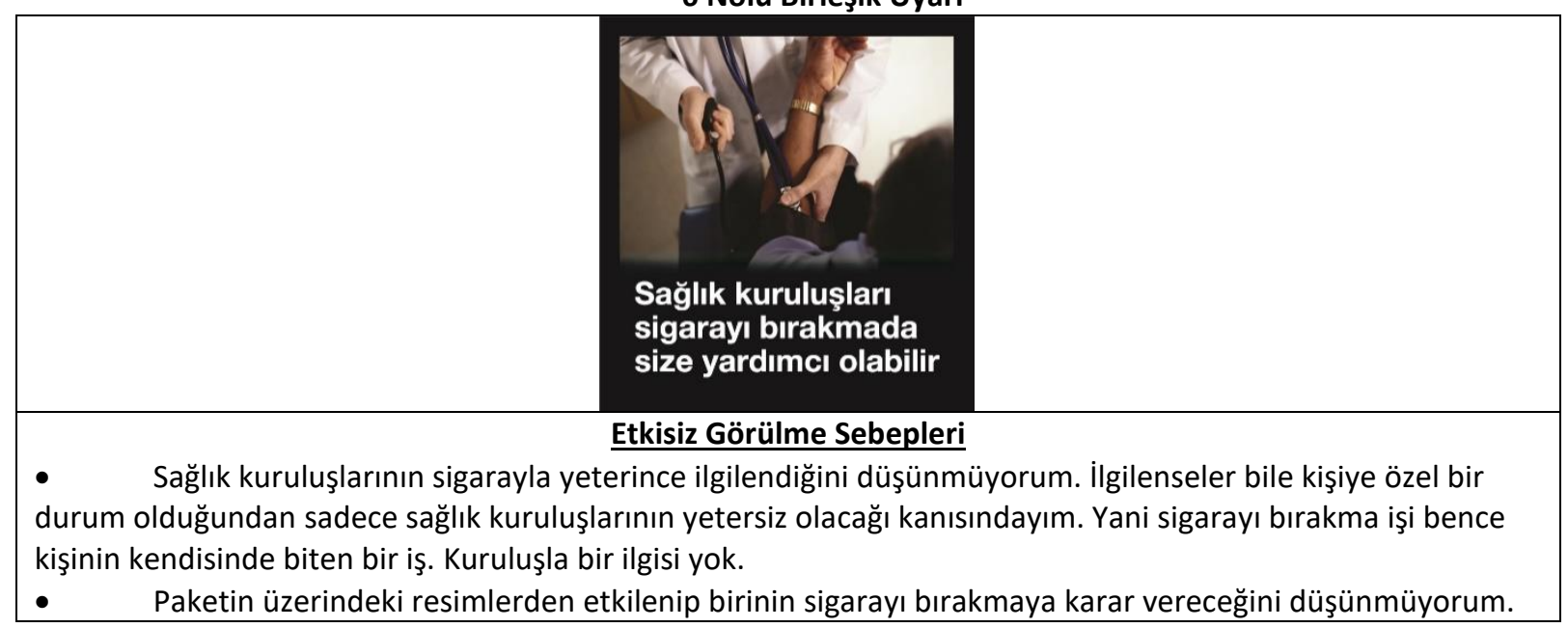


- Kimsenin sigarayı bırakmak için sağlık kurumuna başvuracağını düşünmüyorum. Hastaneler zaten tonla insan kaynıyor.

- $\quad$ Kendi gittiğim sağlık kuruluşunun bu konuda yeterli imkâna sahip olmadığını ve bana yeterli yardımda bulunmadığını bildiğim için bence bu uyarı anlamsız.

- Tansiyon ölçen bir doktor sigarayla ne alakası var anlamadım.

- $\quad$ Yazısını okumadığın sürece bir şey ifade etmiyor.

- $\quad$ Kendim de bir sağlık çalışanı olarak sağlık kuruluşlarının bu anlamda yeterli olduğunu düşünmüyorum.

- $\quad$ Şimdiye kadar hiçbir sağlık kuruluşundan yardım alan görmedim, yardım alanların da azınlık olduğunu düşünüyorum. Eğer kişi yardım alıyorsa zaten bu kişi bilinçli bir bireydir ve yardım almadan da sigarayı bırakabilir

Etkili Görülme Sebepleri

- Diğer görsellere göre daha anlamlı açıklamalar içeriyor

10 Nolu Birleşik Uyarı

\begin{tabular}{|c|c|}
\hline & $\begin{array}{l}\text { Sigarayı bırakmak için } \\
\text { doktorunuzdan ve } \\
\text { size en yakın sağlık } \\
\text { ocağından yardım isteyin }\end{array}$ \\
\hline $\begin{array}{l}\bullet \\
\bullet \\
\bullet \\
\bullet \\
\text { çok az. } \\
\bullet \\
\bullet \\
\bullet \\
\bullet \\
\bullet \\
\bullet \\
\bullet \\
\bullet \\
\text { onlar içi } \\
\bullet \\
\text { duyuyo } \\
\bullet \\
\text { bırakılal } \\
\bullet\end{array}$ & $\begin{array}{l}\text { Etkisiz Görülme Sebepleri } \\
\text { Fotoğraf vermek istediği mesajı tam olarak aktaramıyor. } \\
\text { Fotoğraf saçma geldi; olumsuz değil olumlu bir görsel gibi algılanıyor. } \\
\text { Resim bir şeyin ciddiyetini ortaya koymuyor ve anlaşılır değil. } \\
\text { Bence iradesi sağlam olanlar sigarayı bırakma yoluna gidiyorlar. Tıbbi olarak destek alan bağımlı sayısı } \\
\text { Birbirine kavuşan eller bende sigaranın olumsuz yönleriyle ilgili bir etki yaratmıyor. } \\
\text { Görseller altındaki yazıyı etkili biçimde ifade etmiyor. } \\
\text { Etkisiz çünkü uyarı sigara ile ilgili bir anlam taşımıyor. } \\
\text { Sigara kullanımıyla bağlantılı durmuyorlar. } \\
\text { Görsel etkisiz, yazı uzun. } \\
\text { Innsanların ayrılmaları için onca sebep varken sigara çok gerilerde kalır } \\
\text { Etkili çünkü insanlar bazen sıkıntılarından kurtulmak için bir yol ararlar. } \\
\text { Sigarayı bırakmak isteyip de bunun için uğraşmak yani tedavi olmaya erinen insanlarımız var; bu afiş } \\
\text { in çok faydalı olur. } \\
\text { Bağımlı olduğunun farkına varan birisi bunu la başa çıkabilmek için profesyonel yardıma ihtiyaç } \\
\text { r. Bu açıdan etkili olduğunu düşünüyorum. } \\
\text { Sigara içmenin zararları değil bırakmanın faydalarından söz edilmiştir ve bu da kullanıcılar için } \\
\text { bilir izlenimi yaratmıştır. } \\
\text { Amaca yönelik ve mantıklı bir görsel; diğerleri oldukça itici. }\end{array}$ \\
\hline
\end{tabular}




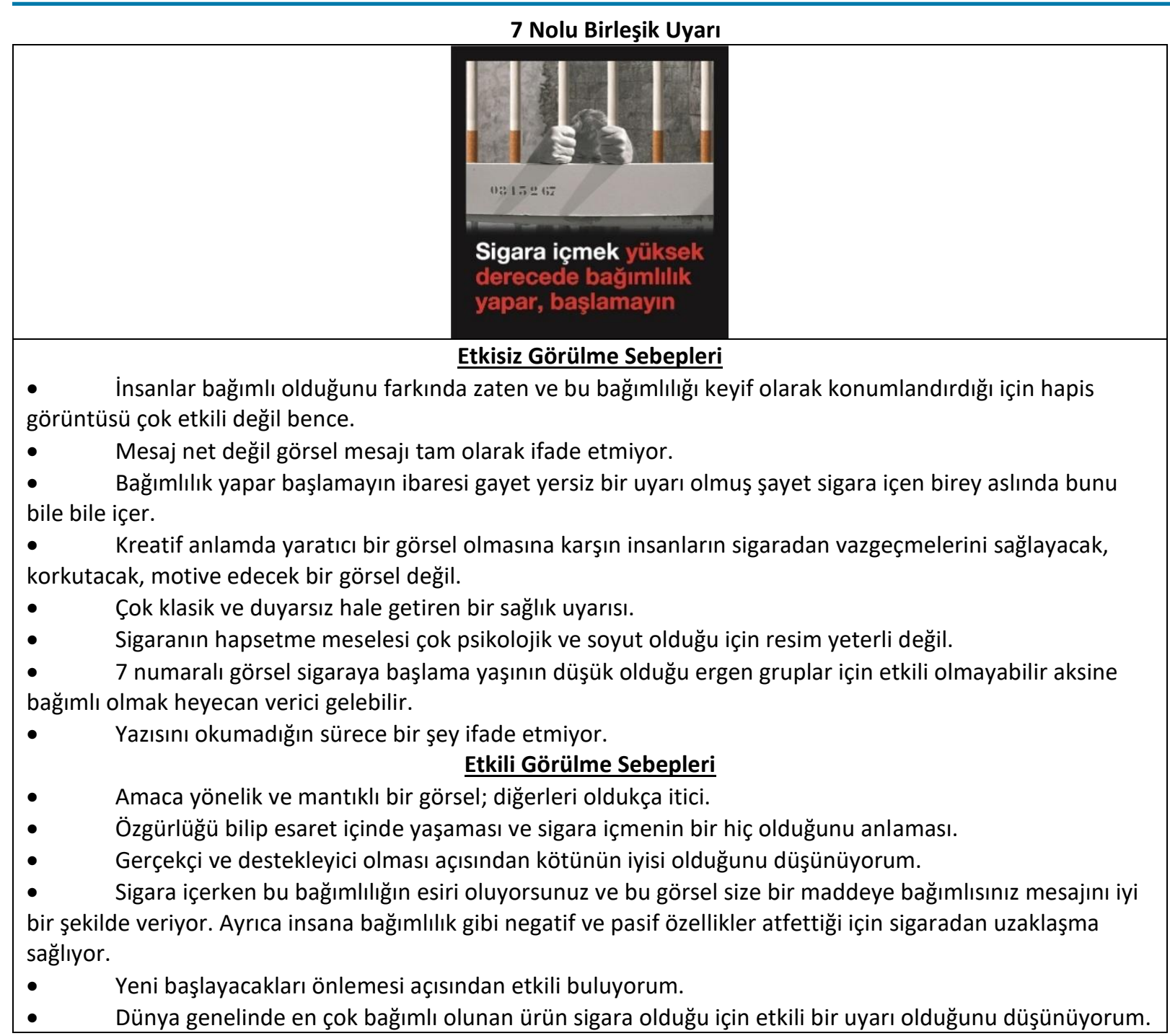

8 Nolu Birleşik Uyarı

\begin{tabular}{|c|c|}
\hline & $\begin{array}{l}\text { Sigarayı bırakmak } \\
\text { ölümcül kalp ve akciğer } \\
\text { hastalıkları riskini azaltır }\end{array}$ \\
\hline & $\begin{array}{l}\text { Etkisiz Görülme Sebepleri } \\
\text { Ucuz, amaçsız bir reklam çalışması ve yapılmış olmak için yapılan bir kamu spotu gibi. } \\
\text { Spor yapmak sağlık açısından önemlidir mesajı veriyor adeta. } \\
\text { Sigara içmekle ilgisiz bir görsel gibi gözüküyor. } \\
\text { Fazla iyimser bir mesaj kimse bırakmak için acele etmez. } \\
\text { Etkili Görülme Sebepleri } \\
\text { Sağlık sorunlarına işaret ettiği için bence etkili bir uyarı. } \\
\text { Sigara içmenin zararları değil bırakmanın faydalarından söz edilmiştir ve bu da kullanıcılar için } \\
\text { bilir izlenimi yaratmıştır. }\end{array}$ \\
\hline
\end{tabular}


12 Nolu Birleşik Uyarı

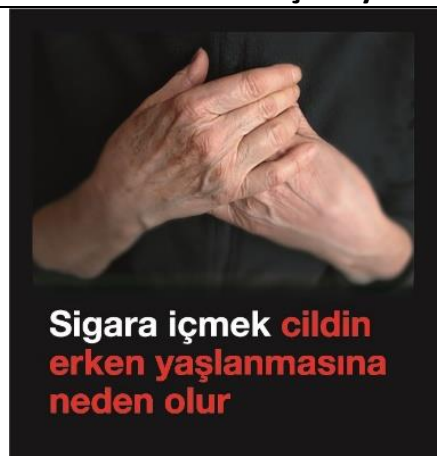

Etkisiz Görülme Sebepleri

- $\quad$ Cilt yaşlanması insanların bu bağımlılıktan kurtaracak derecede etkili değil.

- 12 numaralı resim, sigarayla alakası olmayan orta yaş üstü bir rahip imajı oluşturuyor.

- $\quad$ Insanların çok önem verdiği bir konu olduğunu düşünmüyorum.

- $\quad$ Görselin mesajını almam için alt metni okumam lazım. Açık bir mesaj değil.

- $\quad$ Resme bakında ne demek istediği hemen anlaşılmıyor.

- $\quad$ Sarsıcı bir etkiye sahip değil, ürkütücü değil.

- Söylenen etkileri verilebilecek kanıtların zayıf olduğunu düşünüyorum.

- $\quad$ Cilt yaşlılığı çok önemli değil; hele de resim eller olunca, belki yüz kullanılsa etkileyebilir.

- $\quad$ El yerine çehre kullanılmalıydı.

- $\quad$ Cilt yaşlanması sigara içmeden de yaşanılacak kaçınılmaz bir gerçek.

- $\quad$ Sigara içen kişi ölümü bile düşünmez iken cildinin yaşlanmasını düşüneceğini sanmıyorum.

- $\quad$ Ciltteki kırışıkıklar, hayatımızdaki tecrübelerimizdir.

- $\quad$ Daha çok bayanlara hitap ettiği için etkili bulmuyorum.

- $\quad$ Sigara içen insanlar ilerde yaşayacağı sonuçları yakın gelecekte olanlara göre daha az önemsiyor.

\section{Etkili Görülme Sebepleri}

- Cildin erken yaşlanmasına sebep olması herhangi bir iç organdan daha gözle görülür ve hızlı hissedilir olduğundan daha dikkat çekici ve düşündürücü olabilir.

- $\quad$ Sigara içmenin somut etkileri direkt olarak görselde mevcut. 
This Page Intentionally Left Blank 